\author{
Marta Rojewska \\ ORCID: 0000-0002-2860-6042 \\ VIII LO im. Władysława IV w Warszawie, Uniwersytet Warszawski
}

https://doi.org/10.19195/2450-274X.6.3

\title{
Edukacja europejska w nauczaniu podstaw przedsiębiorczości ${ }^{*}$
}

\begin{abstract}
Abstrakt: Społeczeństwo polskie o edukacji europejskiej wie stosunkowo niewiele, stąd też często formułowane jest $\mathrm{w}$ dyskursie publicznym wezwanie do wprowadzania do polskiej szkoły tak zwanej edukacji europejskiej, która z jednej strony miałaby być edukacją „o Europie”, z drugiej zaś edukacją „dla Europy”. O ile ta pierwsza nie wymaga wyjaśnienia swojego celu, o tyle druga już tak: ma to być nauczanie ukierunkowane na wykształcenie postaw proeuropejskich. Celem niniejszego artykułu jest wykazanie, iż edukacja europejska może i powinna być elementem nauczania przedmiotu podstawy przedsiębiorczości w szkole ponadpodstawowej, choć nie jest to przewidziane jej podstawą programową. W części pierwszej przeanalizowane zostały argumenty świadczące o zasadności uwzględnienia elementów edukacji europejskiej w treściach nauczania podstaw przedsiębiorczości, w tym poparte analizą podstawy programowej kształcenia ogólnego dla liceum ogólnokształcącego i technikum. W części drugiej pojawiła się syntetyczna analiza treści „europejskich”, jakie mogą lub powinny być zrealizowane $\mathrm{w}$ ramach tego przedmiotu. Część trzecia została natomiast poświęcona metodom, środkom i narzędziom, jakie mogą być użyte w czasie „lekcji europejskich” na lekcjach przedsiębiorczości.
\end{abstract}

Słowa kluczowe: edukacja europejska, podstawy przedsiębiorczości, szkoła ponadpodstawowa

\section{European education in teaching the Education for Entrepreneurship}

Abstract: Polish society knows relatively little about European education; hence the public discourse often calls for the introduction of the so-called European education to the Polish school, which on the one hand would be education "about Europe", and on the other hand, education "for Europe". While "education about Europe" does not require an explanation of its purpose, the second one sure does: it should be teaching aimed at developing pro-European attitudes. The aim of this article is to show that European education can be and should be an element of teaching the subject "Education for Entrepreneurship" in secondary schools, although it is not provided for subject's core curriculum. The first part analyzes the arguments justifying the need to include elements of Europe-

* Artykuł został opracowany na podstawie pracy dyplomowej przygotowanej na zakończenie studiów podyplomowych „Przedsiębiorczość dla nauczycieli” realizowanych przez autorkę w latach 2019-2021 w Szkole Głównej Handlowej w Warszawie. 
an education in the content of "Education for Entrepreneurship", including the analysis of the core curriculum of general education for general secondary and technical secondary schools. The second part contains a synthetic analysis of the "European" content that can be or should be implemented within this subject. The third part was devoted to the methods, didactic aids and tools that can be used during "European lessons" in lessons of "Education for Entrepreneurship".

Keywords: European education, Education for Entrepreneurship, secondary school

\section{Wstęp}

Roczniki wchodzące obecnie w bramy szkół ponadpodstawowych to młodzież, która urodziła się już po wstąpieniu Rzeczypospolitej Polskiej (RP) do Unii Europejskiej (UE). W ich świadomości członkostwo we wspólnocie jest czymś oczywistym i naturalnym, jest stanem zastanym. W świadomości ich nauczycieli, rodziców, dziadków jest natomiast czymś, co zostało z trudem wypracowane. Te dwie odmienne perspektywy nie zmieniają jednak jednego - o integracji europejskiej Polacy jako społeczeństwo wiedzą stosunkowo mało, a wiedza ta częstokroć opiera się na stereotypach. Przytoczyć tu można chociażby przykłady absurdów unijnej biurokracji - marchewki jako owocu, krzywizny banana czy wreszcie ślimaka będącego rybą słodkowodną. Jednocześnie jednak te stereotypy mogą być wykorzystane jako egzemplifikacja idei integracji europejskiej, swoisty modus operandi UE, którym jest kompromis i współpraca oparte na interesach wszystkich. Wszak przekwalifikowanie marchewki z warzywa na owoc stanowi ukłon w stronę jednego z państw członkowskich - Portugalii, w której jednym z tradycyjnych przetworów jest właśnie dżem z tego warzywa. Tworząc przepisy umożliwiające dopuszczenie na rynek Wspólnot Europejskich dżemów i marmolad oraz obowiązku informacyjnego na temat ich składu, instytucje wspólnotowe przychyliły się do wniosku tego państwa z 1988 roku o uwzględnienie w nich portugalskiego tradycyjnego produktu, mimo iż wymagało to uznania tego gatunku rośliny $\mathrm{z}$ rodziny selerowatych za owoc ${ }^{1}$. Zgodnie ze wspólnotową definicją dżem ,jest mieszaniną cukrów, miąższu i/lub purée z jednego lub kilku rodzajów owoców i wody, doprowadzoną do odpowiednio żelowej konsystencji” z założeniem, iż ilość miąższu i/lub purée użyta do wytworzenia jednego kilograma produktu nie może być mniejsza niż wskazane wartości ${ }^{2}$. Co ciekawe „do celów niniejszej dyrektywy za owoce uważa się pomidory, jadalne części łodyg rabarbaru, marchew, słodkie

${ }^{1}$ Marchewka zaklasyfikowana jako owoc? To nie absurd, ale uwzględnienie tradycji, w: Fake news czy prawda? Sprawdź!, strona internetowa Przedstawicielstwa Komisji Europejskiej w Polsce, 10.05.2019, https://ec.europa.eu/poland/news/190510_fake_news_pl (dostęp: 5.04.2021).

2 Załącznik nr 1 do dyrektywy Rady 2001/113/WE z dnia 20 grudnia 2001 roku odnoszącej się do dżemów owocowych, galaretek i marmolady oraz słodzonego przecieru z kasztanów przeznaczonych do spożycia przez ludzi, Dz.Urz. UE L 10 z 12.01.2002. 
ziemniaki, ogórki, dynie, melony i arbuzy"3. Podobne wyjaśnienia można znaleźć w przypadku pozostałych przytoczonych przykładów, to jest bananów i ślimaków. Jest to sztuka kompromisu, która w Unii Europejskiej stoi za całą ideą integracji wszakże In varietate concordia.

Unia Europejska niewątpliwie oddziałuje na codziennie życie milionów Europejczyków, a mimo to od lat w systemie edukacji zarówno Polski, jak i innych państw członkowskich traktowana jest „po macoszemu”, co z kolei przekłada się na liczne mity, stereotypy i ogólne zagubienie obywateli w sprawach europejskich. Mityczna, zbiurokratyzowana Bruksela jawi się jako wróg interesów narodowych, zaś bezduszny mechanizm urzędniczy stanowi zagrożenie dla różnorodności. Stąd też od lat pojawiają się wnioski i postulaty, by upowszechniać w polskiej szkole edukację europejską. Zdaniem Katarzyny Hall „edukacja regionalna, patriotyczna i obywatelska oraz europejska powinny mieć swoje miejsce na wszystkich etapach nauczania oczywiście w sposób dostosowany do wieku i możliwości percepcyjnych uczniów. [...] z pewnością zadaniem nauczycieli i wychowawców na każdym etapie edukacyjnym jest kształtowanie u uczniów dobrze pojętego patriotyzmu: lokalnego, regionalnego, narodowego, państwowego oraz europejskiego. Jak to robić? Jak czynić patriotyzm lokalny niesprzecznym $\mathrm{z}$ interesem narodowym, jak sprawiać, aby myślenie propaństwowe mogło być również proeuropejskie?"4. W opinii byłej minister edukacji narodowej odpowiedzią na te potrzeby jest edukacja europejska, która nie ogranicza się do lekcji historii i wiedzy o społeczeństwie, lecz powinna być wpleciona w wiele przedmiotów, tak jak jest w nich od lat zakorzeniona edukacja obywatelska i patriotyczna ${ }^{5}$. Jednym z przedmiotów stwarzających takie możliwości jest przedmiot podstawy przedsiębiorczości (PP), który przewidziany został na III etapie edukacyjnym, to jest w szkole ponadpodstawowej.

Autorka pozwoliła sobie sformułować hipotezę, w myśl której rozszerzenie programu nauczania podstaw przedsiębiorczości o elementy edukacji europejskiej, nie tylko może być pomocne dla lepszego rozumienia przez uczniów procesów gospodarczych zachodzących w Europie i ich świadomości europejskiej, ale także wydaje się elementem koniecznym do pełnego zrozumienia tych procesów, które podstawa programowa tego przedmiotu definiuje jako narodowy system gospodarki rynkowej.

Celem niniejszego artykułu, w którym zastosowana zostanie rozszerzona analiza treści oraz krytyczna analiza źródeł, jest wykazanie, iż edukacja europejska może i powinna być elementem nauczania przedmiotu podstawy przedsiębiorczości w szkole ponadpodstawowej. W części pierwszej przeanalizowane zostaną

3 Załącznik nr 3 do dyrektywy Rady 2001/113/WE.

4 K. Hall, Wprowadzenie, [w:] Edukacja europejska - zarys problematyki, red. T. Michalski, Pelplin 2005, s. 7.

5 Ibidem, s. 7-8. 
argumenty świadczące o zasadności uwzględnienia elementów edukacji europejskiej w treściach nauczania podstaw przedsiębiorczości, w drugiej pojawi się syntetyczna analiza treści, jakie powinny być zrealizowane w ramach tego przedmiotu, w trzeciej zaś metody, środki i narzędzia możliwe do wykorzystania w czasie „lekcji europejskich” na lekcjach PP.

Dla dopełnienia wstępu trzeba jeszcze dookreślić rozumienie tytułowej edukacji europejskiej. Standardowo jest ona określana jako nauka o Unii Europejskiej - jej historii, prawie, instytucjach i politykach. Powinna łączyć w sobie wiedzę historyczną, politologiczną i ekonomiczną ${ }^{6}$. Zdzisław Mach wskazuje natomiast szersze jej znaczenie: edukacja europejska „to zarówno uczenie o Europie, jak też dla Europy, w celu wykształcenia pokoleń przyszłych Europejczyków"7. To drugie rozumienie dyskutowane było już w latach siedemdziesiątych XX wieku na poziomie politycznym. W 1969 roku szefowie państw i rządów Wspólnot Europejskich zlecili instytucjom zbadanie kwestii udziału młodzieży w budowie zjednoczonej Europy. W efekcie, w 1973 roku, opublikowano raport, sporządzony na zlecenie Komisji Europejskiej, zawierający propozycje wkładu do programów nauczania państw członkowskich, w tym „ostrożne i stopniowe wprowadzanie nauki o europejskiej «obywatelskości», opartej głównie na praktykach i instytucjach wspólnotowych, na pluralizmie i na demokracji”" . Jednakże obawy związane z ewentualną harmonizacją podstaw kształcenia spowodowały odstąpienie od dalszych prac, w kolejnych dekadach zaś na poziomie unijnym prowadzono jedynie projekty promujące idee europejskie skierowane do chętnych ośrodków kształcenia na różnych etapach edukacyjnych ${ }^{9}$. W samej Polsce wzrost zainteresowania tematami europejskimi i początek kształtowania się edukacji europejskiej, co oczywiste, związany jest z procesem akcesyjnym ${ }^{10}$. O ile dyskusja na bazie raportu z 1973 roku dotyczyła bardziej edukacji europejskiej w rozumieniu „wychowania” (za Machem: dla Europy), o tyle ta polska zawsze była związana jedynie z „nauczaniem” (o Europie). Na potrzeby artykułu edukację europejską rozumieć należy jako naukę o sprawach europejskich - o zjednoczonej Europie, o procesie integracji i jej efektach.

6 A. Przybysz, Europejski wymiar szkolnictwa wyższego, „Edukacyjne dyskursy. Internetowe Pismo Pedagogiczne Instytutu Pedagogiki Uniwersytetu Szczecińskiego", 15.06.2004, http://www. edukacyjne.dyskursy.univ.szczecin.pl/europejski.htm (dostęp: 5.04.2021).

7 Cyt. za: A. Włoch, Edukacja europejska. Założenia, perspektywy, funkcje społeczne. Krytyczne spojrzenie, Kraków 2016, s. 19.

8 For a Community policy on education. Report by Henri Janne, „Bulletin of the European Communities. Supplement" 10/73, s. 52.

9 J. Truszczyński, Edukacja europejska a procesy rozszerzenia i budowy Unii Europejskiej, [w:] Polska w Unii Europejskiej - od stowarzyszenia do piętnastolecia członkostwa. Monografia jubileuszowa dedykowana Profesor Elżbiecie Kaweckiej-Wyrzykowskiej, red. A.A. Ambroziak, A.D. Szypulewska-Porczyńska, Warszawa 2020, s. 470-471.

10 Ibidem, s. 473. 


\section{Miejsce edukacji europejskiej w podstawie programowej kształcenia ogólnego i przedmiocie podstawy przedsiębiorczości}

Integracja europejska, kreowana jako idea od lat dwudziestych XX wieku ${ }^{11}$, stała się rzeczywistością, w której w latach dwudziestych XXI wieku na co dzień funkcjonuje 446 milionów Europejczyków. Szacuje się, że nawet $60 \%$ kompetencji ustawodawczych utraciły parlamenty narodowe na skutek przedmiotowego rozszerzania integracji, jeśli uwzględnić zakres spraw regulowanych na poziom UE ${ }^{12}$. Nie dziwi to jednak, jeśli spojrzeć na to, jak szeroko zakrojone są kompetencje tej organizacji - nie tylko kompetencje wyłączne, ale i dzielone, a nawet koordynujące, wspierające i uzupełniające ${ }^{13}$. Dziś wręcz truizmem byłoby stwierdzenie, że „Unia Europejska jest wszędzie wokół nas" — od infrastruktury rozbudowywanej dzięki funduszom unijnym, przez preferencyjne stawki roamingu na jej terenie, po oznaczenia i etykiety na produktach spożywczych, które muszą być zgodne z wymogami prawa UE. Jak się jednak wydaje, wiedza na temat Unii Europejskiej bywa wybiórcza i niejednokrotnie ograniczona, co zresztą zostało już zaznaczone we wstępie niniejszej pracy. Niejednokrotne mylenie w mediach Rady Europy z Radą Europejską i Radą Unii Europejskiej to tylko wierzchołek przysłowiowej góry lodowej. Zwłaszcza tematy obejmujące wiedzę z zakresu Wspólnego Rynku, strefy euro, działania Unii Gospodarczej i Walutowej (UGW) nie są znane w stopniu zadowalającym, mimo iż dotyczą bezpośrednio rzeczywistości i przyszłości Polaków ${ }^{14}$.

Od lat w standardowym badaniu opinii publicznej Eurobarometr pojawiało się pytanie „Co uznajesz za najbardziej pozytywne osiągnięcia UE?”, w którym można było zaznaczyć trzy odpowiedzi spośród: cztery swobody Wspólnego Rynku, ekonomiczna siła UE, euro, pokój między państwami, polityczny i dyplomatyczny wpływ UE w świecie, poziom opieki społecznej, studenckie programy wymiany (na przykład Erasmus), Wspólna Polityka Rolna. W badaniu z wiosny 2017 roku w skali europejskiej 58\% wskazań uzyskał pokój, 57\% swobody Wspólnego Rynku, a po $25 \%$ euro i Erasmus ${ }^{15}$. W tym samym badaniu Polacy wskazywali najczęściej cztery swobody Wspólnego Rynku (64\%), a dopiero w dalszej kolejności pokój

11 Więcej zob. M. Rojewska, Ewolucja myśli europejskich ruchów federalistycznych, „Myśl Ekonomiczna i Polityczna” 2018, nr 1 (60).

12 J. Barcz, Parlamenty narodowe w procesie integracji europejskiej. Wyzwania przed parlamentem polskim, [w:] R. Arnold et al., Parlament Europejski oraz parlamenty Polski i Niemiec w nowej architekturze europejskiej, Warszawa 2005, s. 133.

13 Por. art. 2-6 Traktatu o funkcjonowaniu Unii Europejskiej, wersja skonsolidowana, Dz Urz. UE C 202 z dnia 7.06.2016 (dalej: TFUE).

14 Oczywiście jeśli założymy, że przyjęcie waluty euro nie sprowadza się do pytania „czy?”, ale „kiedy?”.

15 Standard Eurobarometer 87. Spring 2017. Graphs EN - European citizenship, s. 20, https:// ec.europa.eu/commfrontoffice/publicopinion/index.cfm/ResultDoc/download/DocumentKy/82865 (dostęp: 5.04.2021). 
(58\%), siłę gospodarczą UE (25\%), Erasmusa i inne programy (21\%), zaś euro cieszyło się najmniejszą popularnością $(10 \%)^{16}$. W przypadku wspólnej waluty dość wyraźnie widać, że za osiągnięcie jest ona uznawana dużo częściej w państwach strefy euro (32\%) niż poza nią $(10 \%)^{17}$. Nie da się jednak ukryć, że kwestie gospodarcze i podstawa Wspólnego Rynku mają dla Polaków ogromne znaczenie.

W tych samych badaniach opinii publicznej, choć tym razem przeprowadzonych jesienią 2019 roku, zapytano Europejczyków o ich ogólną wiedzę na temat funkcjonowania Unii Europejskiej. Co ciekawe, przy średniej europejskiej wynoszącej 59\%, aż 75\% Polaków odpowiedziało, że zgadza się ze stwierdzeniem „Wiem, jak działa Unia Europejska" ${ }^{18}$. Analiza demograficzna w wiosennej edycji tego badania pokazała wyraźnie, że wiedza ta (postrzegana oczywiście subiektywnie) jest wśród Polaków odwrotnie proporcjonalna do wieku respondentów $-85 \%$ respondentów w wieku 15-24 lata zgodziło się z powyższym stwierdzeniem, podobnie wypadły grupy wiekowe 25-39 i 40-55, zaś w grupie 55+ odsetek ten wyniósł już tylko $68 \%{ }^{19}$. Problemy pojawily się natomiast w przypadku badania wiedzy obiektywnej - choćby w listopadzie 2019 roku na pytanie o to, czy do strefy euro należy 19 państw członkowskich - tylko $47 \%$ ankietowanych odpowiedziało poprawnie, co i tak wypada relatywnie dobrze na tle średniej unijnej wynoszącej $35 \%{ }^{20}$. Niewielkie znaczenie tematu euro $\mathrm{w}$ wiedzy Polaków pokazuje również raport $\mathrm{z}$ „Badania świadomości i wiedzy ekonomicznej Polaków” przeprowadzonego w 2020 roku na zlecenie Narodowego Banku Polskiego, w którym zaledwie 28\% respondentów umiało poprawnie odpowiedzieć na pytanie, czy monety euro we wszystkich krajach są takie same ${ }^{21}$. Co więcej, 57\% Polaków ocenia, iż ich wiedza na temat strefy i waluty euro jest „bardzo mała i mała”, co potwierdza obiektywnie zbadana wiedza - 72\% badanych wykazało się niską wiedzą w tym zakresie, a jednocześnie jedynie $26 \%$ respondentów odczuwało potrzebę uzupełnienia wiedzy w tym obszarze ${ }^{22} \mathrm{Na}$ marginesie, jako przyczynek do późniejszych rozważań, dodać warto, że aż 64\% respondentów uznaje, iż to szkoła i nauczyciele są w głównej mierze odpowiedzialni za edukację w zakresie finansów, ekonomii, gospodarki ${ }^{23}$.

16 Standard Eurobarometer 87. Spring 2017. The key indicators. Poland, s. 4, https://ec.europa. eu/commfrontoffice/publicopinion/index.cfm/ResultDoc/download/DocumentKy/79546 (dostęp: 5.04.2021).

17 Standard Eurobarometer 87. Spring 2017. Graphs EN..., s. 22.

18 Standard Eurobarometer 92. Autumn 2019. Public opinion in the European Union. Raport, s. 160, https://ec.europa.eu/commfrontoffice/publicopinion/index.cfm/ResultDoc/download/DocumentKy/90258 (dostęp: 5.04.2021).

19 Standard Eurobarometer 91. Spring 2019. Public opinion in the European Union. Report, s. 133, https://ec.europa.eu/commfrontoffice/publicopinion/index.cfm/ResultDoc/download/DocumentKy/88420 (dostęp: 5.04.2021).

20 Standard Eurobarometer 92..., s. 163.

21 Narodowy Bank Polski. Departament Edukacji i Wydawnictw NBP, Prezentacja wyników „Badania świadomości i wiedzy ekonomicznej Polaków”, s. 26, https://www.nbp.pl/edukacja/badania/ wiedza-ekonomiczna-polakow.pdf (dostęp: 5.04.2021).

22 Ibidem, s. 31, 39.

23 Ibidem, s. 41. 
Powyżej przytoczone dane, z założenia koncentrujące się na wspólnej walucie, są oczywiście jedynie wąską egzemplifikacją rozbieżności między obiektywną wiedzą Polaków a ich subiektywną oceną w tym względzie. W tym miejscu pojawia się kolejny aspekt wynikający $\mathrm{z}$ analizy badań opinii publicznej. Typowym mechanizmem, pewnym skryptem myślowym jest obawa przed tym, co nieznane. Mimo ogólnie pozytywnego podejścia do Unii Europejskiej, Polacy są jednym z bardziej sceptycznych społeczeństw UE. W listopadzie 2019 roku aż $42 \%$ respondentów uważało, że ich państwo lepiej poradziłoby sobie z wyzwaniami przyszłości, pozostając poza Unią Europejską, podczas gdy średnia unijna to $29 \%{ }^{24}$. Od lat mamy też dość wysoki odsetek osób niechętnych wprowadzeniu waluty euro - 55\% przeciwników i 35\% zwolenników w roku 2019²5. Jak więc społeczeństwo chce prowadzić merytoryczną dyskusję nad przyjęciem wspólnej waluty, jeśli jednocześnie samo ocenia negatywnie stan swojej wiedzy? Zupełnie na marginesie warto wspomnieć, że pewnego rodzaju pożywką dla działalności populistycznych i najczęściej również nacjonalistycznych partii i ruchów politycznych jest właśnie brak wiedzy o działaniu procesów politycznych. Skutki tego widać chociażby w zaskoczeniu Brytyjczyków swoją własną decyzją przy referendalnych urnach w roku 2016 roku, która to decyzja urzeczywistniła się 1 lutego 2020 roku $^{26}$, gdy liczba państw członkowskich zmniejszyła się o jedno.

Kluczowym aspektem wydaje się więc budowanie wiedzy o Unii Europejskiej tak, aby dyskusja nad uczestnictwem w tym projekcie mogła toczyć się w oparciu o argumenty, a nie hasła, stereotypy i emocje. Senat Rzeczypospolitej Polskiej 18 czerwca 2020 roku podjął uchwałę o znaczeniu edukacji europejskiej, w której „apeluje o wzmożenie istniejących działań i podejmowanie nowych inicjatyw na rzecz edukacji o Unii Europejskiej [...] O nadanie nowego impulsu i nowego zakresu europejskiemu wymiarowi edukacji. Chodzi o intensyfikację popularyzowania wiedzy o integracji europejskiej i objęcie nią wszystkich grup wiekowych, wszystkich grup zawodowych i wszystkie regiony kraju. Apel skierowany jest do wszystkich jednostek nauczania i wychowania, do nauczycieli i wychowawców, do samorządów wszystkich szczebli, do organizacji pozarządowych oraz do mediów. [...] Generalnie edukacja o Europie to wiedza o historii integracji europejskiej, o podstawach prawnych funkcjonowania Unii Europejskiej, o zależnościach prawa krajowego i eu-

24 Standard Eurobarometer 92..., s. 108.

25 Dla porównania w roku 2014 odnotowano 68\% przeciwników i 24\% zwolenników. B. Roguska, Narastanie obaw związanych z wprowadzaniem euro, CBOS, Komunikat z badań 151/2014, listopad 2014, www.cbos.pl/SPISKOM.POL/2014/K_151_14.PDF, s. 6; Standard Eurobarometer 91. Spring 2019. Europeans' views on the priorities of the European Union. Report, s. 23, https://ec.europa. eu/commfrontoffice/publicopinion/index.cfm/ResultDoc/download/DocumentKy/88102 (dostęp: 5.04.2021).

$26 \mathrm{~W}$ niespełna dwa miesiące po przeprowadzonym referendum wzrost poparcia dla pozostania w Unii Europejskiej wzrósł na wyspie z 49\% do 57\%. Brexit has raised support for the European Union, „flashlight Europe” 2, 2016, Bertelsmann Stiftung, https://www.bertelsmann-stiftung.de/ fileadmin/files/user_upload/EZ_flashlight_europe_02_2016_EN.pdf (dostęp: 5.04.2021). 
ropejskiego, o prawach i obowiązkach członków Unii, a także wiedza o krajach członkowskich, naszych europejskich sąsiadach"27.

Wydaje się więc, że budowanie rzetelnej wiedzy o Unii Europejskiej jest obowiązkiem szkoły i nauczycieli, co zresztą potwierdzają przytoczone wcześniej badania opinii publicznej. Tym samym pojawia się pytanie o miejsce problematyki europejskiej w podstawie programowej kształcenia ogólnego.

Wiodącym przedmiotem w zakresie edukacji europejskiej jest, co oczywiste, wiedza o społeczeństwie (WOS). Edukacja europejska pojawia się tu zarówno na poziomie podstawowym (realizowanym w liceum ogólnokształcącym i technikum przez dwa lata $w$ wymiarze jednej godziny na tydzieńn ${ }^{28}$ ), jak i na poziomie rozszerzonym (realizowanym w wymiarze kolejnych 8 godzin tygodniowo w ciągu czteroletniego liceum ogólnokształcącego i pięcioletniego technikum) ${ }^{29}$. Analizując jednak podstawę programową dla tych dwóch typów szkół, należy zaznaczyć, że przede wszystkim na poziomie podstawowym brakuje miejsca na ekonomiczny wymiar edukacji europejskiej. Pojawić się może ona jedynie w punkcie „[Uczeń] rozważa kwestię korzyści i kosztów członkostwa Rzeczypospolitej Polskiej w Unii Europejskiej”30. Jednakże w skali jednej godziny lekcyjnej można zaledwie pobieżnie wspomnieć o takich elementach integracji, jak wspólna waluta, cztery swobody Wspólnego Rynku czy Unia Gospodarcza i Walutowa.

W zakresie rozszerzonym WOS przebieg integracji gospodarczej, strefa euro, Europejski Bank Centralny (EBC) pojawiają się już wprost w podstawie programowej. I tak, zgodnie z punktem 14 podstawy pod tytułem „Integracja europejska", uczeń, między innymi:

- 14.3. „przedstawia integrację w ramach Unii Europejskiej (w aspekcie gospodarczym - od wspólnego rynku do unii gospodarczo-walutowej)",

- 14.9. „wyjaśnia założenia strefy euro; przedstawia zadania Europejskiego Banku Centralnego i Europejskiego Systemu Banków Centralnych”;

- 14.10. „przedstawia dochody i wydatki budżetowe Unii Europejskiej i procedurę tworzenia budżetu ogólnego";

- 14.11. „charakteryzuje działalność Unii Europejskiej w polityce [...] konkurencji i ochrony konsumentów"31.

27 Uchwała Senatu Rzeczypospolitej Polskiej z dnia 18 czerwca 2020 r. o znaczeniu edukacji europejskiej, Dz.Urz. RP „Monitor Polski” z 2020 r. poz. 596.

28 W liceum w klasie I i II, w technikum w klasie IV i V.

29 Załącznik nr 4 i 5 rozporządzenia Ministra Edukacji Narodowej z dnia 3 kwietnia 2019 roku w sprawie ramowych planów nauczania dla publicznych szkół, Dz.U. z 2019 r. poz. 639 z późn. zm.

30 Pkt 7.10, Wiedza o społeczeństwie. Zakres podstawowy. Treści nauczania - wymagania szczegółowe, [w:] załącznik nr 1 rozporządzenia Ministra Edukacji Narodowej z dnia 30 stycznia 2018 roku $w$ sprawie podstawy programowej kształcenia ogólnego dla liceum ogólnokształcącego, technikum oraz branżowej szkoly II stopnia, Dz.U. z 2018 r. poz. 467 z późn. zm.

31 Pkt 14.3, 14.9-11, Wiedza o społeczeństwie. Zakres rozszerzony. Treści nauczania - wymagania szczegółowe, [w:] załącznik nr 1 rozporządzenia Ministra Edukacji Narodowej z dnia 30 stycznia 2018 roku... 
Z perspektywy działania Unii Gospodarczej i Walutowej UE założenia podstawy programowej są zgodne $\mathrm{z}$ oczekiwaniami dotyczącymi poruszanych treści. Pojawiają się jednak dwa zasadnicze problemy. Pierwszy z nich to liczba godzin, jaką zgodnie z rozkładem materiału można przeznaczyć na ich realizację. Tabela 1 przedstawia rozdział treści z zakresu integracji europejskiej (kolumna 2) i przeznaczoną na nie liczbę godzin (kolumna 3).

Tabela 1. Rozkład godzin lekcyjnych w temacie „Unia Europejska” w podstawie programowej WOS (zakres rozszerzony)

\begin{tabular}{|c|c|c|c|}
\hline \multicolumn{3}{|c|}{ Unia Europejska } & \\
\hline 1. integracja europejska & $\begin{array}{l}\text { geneza i etapy integracji, charakter prawny UE, } \\
\text { postanowienia traktatów unijnych, państwa } \\
\text { członkowskie UE }\end{array}$ & 2 & $\begin{array}{c}\text { ZP: } 7.9 \\
\text { ZR: } 14.1-14.4\end{array}$ \\
\hline 2. instytucje UE & $\begin{array}{c}\text { Rada Europejska, Parlament Europejski, Komisja } \\
\text { Europejska, Rada UE, Trybunał Sprawiedliwości } \\
\text { UE }\end{array}$ & 2 & $\begin{array}{c}\text { ZP: } 7,8,7.9 \\
\text { ZR: } 14.5-14.7\end{array}$ \\
\hline 3. funkcjonowanie UE & $\begin{array}{c}\text { działanie UE w sferze wymiaru sprawiedliwości } \\
\text { i spraw wewnętrznych, polityka zagraniczna oraz } \\
\text { bezpieczeństwa i obrony UE, strefa euro i EBC, } \\
\text { dochody i wydatki UE, procedura tworzenia } \\
\text { budżetu unijnego, polityki sektorowe, fundusze } \\
\text { europejskie }\end{array}$ & 3 & ZR: $14.7-14.14$ \\
\hline 4. perspektywy UE & $\begin{array}{l}\text { przyszłość UE w zakresie zadań i struktury, } \\
\text { perspektywy rozszerzenia UE }\end{array}$ & 1 & ZE: 14.15 \\
\hline podsumowanie i test & & 2 & \\
\hline
\end{tabular}

Źródło: B. Furman, W centrum uwagi. Program nauczania wiedzy o społeczeństwie dla liceum ogólnokształcącego i technikum zakres rozszerzony ze zintegrowanymi treściami z zakresu podstawowego, Warszawa 2019, s. 49.

Zasadniczy więc problem dotyczy czasu przeznaczonego na te tematy de facto pół lekcji w ramach historii integracji europejskiej i jedna lekcja na obszary 14.9-14.10. Drugi, o wiele istotniejszy problem dotyczy liczby klas, które realizują program rozszerzony z WOS. W roku 2020 do egzaminu maturalnego na poziomie rozszerzonym $\mathrm{z}$ wiedzy o społeczeństwie przystąpiło 17073 osoby w całej Polsce spośród 259272 zdających, co stanowi 6,58\% ${ }^{32}$. W rekrutacji na rok szkolny 2020/2021 spośród 171 szkół publicznych w Warszawie tylko 64 licea ogólnokształcące miały klasy z rozszerzonym programem tego przedmiotu. Żadne technikum nie prowadziło rekrutacji do takiej klasy ${ }^{33}$. Oczywiście jest to przykład tylko jednego miasta i jednego roku szkolnego, lecz pokazuje zasadniczy problem:

32 Centralna Komisja Egzaminacyjna, Wstępne informacje o wynikach egzaminu maturalnego przeprowadzonego w terminie głównym (w czerwcu) 2020 r., 11.08.2020, http://cke.gov.pl/images/_ EGZAMIN_MATURALNY_OD_2015/Informacje_o_wynikach/2020/20200811\%20Wstepne\%20 informacje\%20o\%20wynikach\%20egzaminu\%20maturalnego\%202020.pdf, s. 2, 5.

33 Portal Sięgnij po więcej, wyszukiwarka szkół ponadpodstawowych prowadzonych przez m.st. Warszawę, https://wyszukiwarka.spw.edu.pl/ (dostęp: 5.04.2021). 
znakomita większość uczniów - a podkreślić należy, że zwykle jest to tylko jedna klasa na kilka rekrutowanych w danej szkole w danym roczniku - nie będzie miała tych treści realizowanych.

Kolejnym przedmiotem zawierającym elementy edukacji europejskiej, a realizowanym w szkole ponadpodstawowej (w liceum ogólnokształcącym i w technikum w liczbie czterech godzin na poziomie podstawowym oraz sześciu kolejnych godzin na poziomie rozszerzonym w całym cyklu nauczania ${ }^{34}$ ) jest geografia. W podstawie programowej do poziomu podstawowego w dziale „Podział polityczny i zróżnicowanie poziomu rozwoju społeczno-gospodarczego świata” znajduje się punkt „[Uczeń] przedstawia przyczyny oraz pozytywne i negatywne skutki integracji politycznej i gospodarczej na świecie, ze szczególnym uwzględnieniem Unii Europejskiej oraz procesów dezintegracyjnych na wybranych przykładach"35. Na realizację całego działu przewidziano siedem godzin lekcyjnych, przy czym sam dział liczy osiem punktów ${ }^{36}$. Na poziomie rozszerzonym uczeń w ramach działu „Współpraca i konflikty”, omawiając „ważniejsze” organizacje międzynarodowe, także „wyjaśnia rolę ważniejszych międzynarodowych organizacji w życiu politycznym, społecznym i gospodarczym różnych regionów świata, w tym znaczenie Unii Europejskiej w przemianach społeczno-gospodarczych państw zintegrowanych”, z kolei w dziale „Problemy polityczne współczesnego świata” — „dyskutuje na temat głównych problemów funkcjonowania Unii Europejskiej"37. Pierwszy ze wskazanych działów obejmuje trzy obszary tematyczne, a na jego realizację przewidziano trzy godziny; na drugi z nich - obejmujący pięć punktów — pięć godzin $^{38}$. We wszystkich wskazanych przypadkach na tematy europejskie można poświęcić maksymalnie jedną godzinę na poziomie podstawowym i trzy w klasach realizujących poziom rozszerzony. Trzeba zaznaczyć, że podobnie jak w przypadku wiedzy o społeczeństwie, klas realizujących ten przedmiot na tym drugim poziomie jest ograniczona liczba. I tak we wspominanej rekrutacji w Warszawie takich szkół było 98, z czego 16 to technika, a pozostałe to licea ogólnokształcące (na 171 szkół) ${ }^{39}$. Maturę rozszerzoną z geografii w roku 2020 zdawało 68697 osób na 259272 zdających, to jest $26,5 \%$ uczniów $^{40}$. Geografia nie daje więc wiele więcej szans na uwzględnienie ekonomicznej edukacji europejskiej. Tym samym pojawia się pytanie o to, gdzie te tematy wprowadzić.

34 Załącznik nr 4 i 5 rozporządzenia Ministra Edukacji Narodowej z dnia 3 kwietnia 2019 roku...

35 Pkt 7.4, Geografia. Zakres podstawowy. Treści nauczania - wymagania szczegółowe, [w:] załącznik nr 1 rozporządzenia Ministra Edukacji Narodowej z dnia 30 stycznia 2018 roku...

36 Geografia. Warunki i sposób realizacji, [w:] załącznik nr 1 rozporządzenia Ministra Edukacji Narodowej z dnia 30 stycznia 2018 roku...

37 Pkt. 7.2, 20.3, Geografia. Zakres rozszerzony. Treści nauczania - wymagania szczegółowe, [w:] załącznik nr 1 rozporządzenia Ministra Edukacji Narodowej z dnia 30 stycznia 2018 roku...

38 Geografia. Warunki i sposób realizacji, [w:] załącznik nr 1 rozporządzenia Ministra Edukacji Narodowej z dnia 30 stycznia 2018 roku...

39 Portal Sięgnij po więcej, wyszukiwarka szkół...

40 Centralna Komisja Egzaminacyjna, Wstępne informacje..., s. 2 i 4. 
Załącznik nr 1 do rozporządzenia Ministra Edukacji Narodowej z dnia 30 stycznia 2018 roku w sprawie podstawy programowej kształcenia ogólnego dla liceum ogólnokształcącego, technikum oraz branżowej szkoły II stopnia określa założenia i węzłowe cele tejże podstawy. W przypadku przedmiotu podstawy przedsiębiorczości określono, iż uczniowie powinni „posiadać podstawową wiedzę nie tylko z zakresu nauk ścisłych, przyrodniczych i humanistycznych, ale także społecznych, a zwłaszcza ekonomicznych. Wiedza ta daje podstawy do kształtowania umiejętności oraz postaw przedsiębiorczych potrzebnych do funkcjonowania we współczesnej, globalnie uwarunkowanej gospodarce" 41 . Jak się wydaje, mówienie o globalnych uwarunkowaniach gospodarki przekierowuje wprost do Unii Europejskiej - nie dość, że podmiotu kształtującego tę gospodarkę w skali regionu (Europy) w sposób znaczący, to jeszcze będącego jednym z najważniejszych graczy na arenie światowej (Unia jako mocarstwo gospodarcze).

Podstawy przedsiębiorczości są przedmiotem realizowanym przez dwa lata w wymiarze jednej godziny na tydzień (II i III klasa) ${ }^{42}$. Podstawa programowa tego przedmiotu expressis verbis przewiduje tylko jeden punkt, w którym pojawia się jakiekolwiek nawiązanie do integracji europejskiej, a konkretnie wskazanie funduszy unijnych jako możliwego źródła finansowania zakładanej działalności gospodarczej $^{43}$. A mimo to znajdują się w niej liczne treści, które wpisywałyby się w edukację europejską i w wielu punktach pojawiają się do tego istotne przesłanki; tematy, które warto by było uzupełnić o kontekst europejski. Analiza tychże pojawi się w kolejnej części artykułu, w tym miejscu warto jednak wskazać na dwa kolejne powody dla poszerzenia zajęć z PP o edukację europejską.

$\mathrm{W}$ pierwszej kolejności należy podkreślić, że w podstawie programowej PP wskazano, iż na realizację treści przeznaczyć powinno się łącznie 52 godziny, co stanowi $80 \%$ wszystkich godzin przeznaczonych na ten przedmiot, a to oznacza, że do zagospodarowania pozostaje trzynaście godzin ${ }^{44}$. Odliczywszy godziny na powtórzenia i sprawdziany po każdym dziale (czyli osiem godzin), maksymalnie na edukację europejską można przeznaczyć pięć godzin. W rozporządzeniu wprost stwierdzono, iż „Pozostałe godziny nauczyciel może przeznaczyć na rozszerzenie określonych treści według własnego uznania" 45 .

Zasadniczą wątpliwość budzą użyte w rozporządzeniu określenia. „Kształcenie w zakresie przedsiębiorczości powinno rozpocząć się od przedstawienia, czym są, jak funkcjonują i rozwijają się narodowe systemy gospodarek rynkowych. W dzia-

41 Załącznik nr 1 rozporządzenia Ministra Edukacji Narodowej z dnia 30 stycznia 2018 roku...

42 Załącznik nr 4 i 5 rozporządzenia Ministra Edukacji Narodowej z dnia 3 kwietnia 2019 roku...

43 Pkt 4.8, Podstawy przedsiębiorczości. Treści nauczania - wymagania szczegółowe, [w:] załącznik nr 1 rozporządzenia Ministra Edukacji Narodowej z dnia 30 stycznia 2018 roku...

44 Podstawy przedsiębiorczości. Warunki i sposób realizacji, [w:] załącznik nr 1 rozporządzenia Ministra Edukacji Narodowej z dnia 30 stycznia 2018 roku...

45 Ibidem. 
le pierwszym wyjaśnia się ich odmienności wynikające z realizowanych celów, różnej roli państwa i rynku w tych systemach oraz wykorzystywanych przez nie podstawowych czynników wzrostu i rozwoju, takich jak: surowce, praca, inwestycje rzeczowe i kapitałowe, innowacje, handel czy konsumpcja"46. Wydaje się to dziwne sformułowanie w dokumencie programowym kształcenia młodych Europejczyków. Państwo członkowskie Unii Europejskiej jest jednak znacząco ograniczone w swoich decyzjach gospodarczych jako uczestnik Wspólnego Rynku, nie jest to więc funkcjonowanie typowej gospodarki narodowej. Cztery swobody Jednolitego Rynku - swobodny przepływ towarów, usług, kapitału i osób - mocno rzutują na działanie polskiej gospodarki. Wydaje się więc, że omówienie zasad funkcjonowania UGW, w ramach której działa system gospodarczy Rzeczypospolitej, i wykazanie jej wpływu na procesy gospodarcze zachodzące w RP jest koniecznością dla pełnego zrozumienia tych procesów przez uczniów. Praktycznie dopiero w ostatnich zdaniach podstawy programowej podstaw przedsiębiorczości pojawia się w ogóle Unia Europejska: „Warto podkreślić też istotne korelacje z innymi przedmiotami, przede wszystkim z: [...] wiedzą o społeczeństwie, w ramach której zarówno w szkole podstawowej, jak i ponadpodstawowej realizowane są takie zagadnienia, jak: funkcjonowanie Unii Europejskiej [...] [oraz] historią wraz z elementami historii gospodarczej, w tym historii pieniądza i bankowości na ziemiach polskich, etapów rozwoju Unii Europejskiej oraz transformacji gospodarczej w Polsce" 47 . Ta ostatnia uwaga nie wydaje się jednak satysfakcjonująca, zwłaszcza że wykazano już istotne ograniczenia czasowe w lekcjach wiedzy o społeczeństwie i geografii. Skoro istnieje więc sposobność do wprowadzenia edukacji europejskiej do PP, w kolejnych rozdziałach przeanalizowane zostanie, czego i jak uczyć.

\section{Możliwe treści nauczania z zakresu edukacji europejskiej w przedmiocie podstawy przedsiębiorczości}

Jak zostało wskazane w poprzedniej części, w podstawie programowej przedmiotu podstawy przedsiębiorczości znajduje się wiele tematów i zagadnień, które mają lub wręcz powinny mieć swój europejski kontekst. W założeniu tej części artykułu analiza podstawy ma na celu wskazanie pewnego wachlarza możliwości poszerzenia treści, pozostającego do dyspozycji nauczyciela przedmiotu, który może go dowolnie wykorzystać, dobierając tematy do zainteresowań uczniów i swoich preferencji. Oczywiście, co warto zaznaczyć, autorka nie stawia sobie za cel wy-

\footnotetext{
46 Ibidem.

47 Ibidem.
} 
czerpana wszystkich treści, przede wszystkim mając świadomość tego, jak bardzo obszerny jest to temat, po drugie pragnąc zaakcentować kluczowe zagadnienia.

Dział I podstawy pod tytułem "Gospodarka rynkowa" 48 zakłada dokonanie charakterystyki gospodarki wolnorynkowej - jej podmiotów, mechanizmów, cech na tle gospodarki centralnie planowanej, a także rodzajów rynku, faz cyklu koniunkturalnego oraz konkurencji i konsumentów na rynku. Zwłaszcza ten ostatni element pozostawia przestrzeń dla omówienia rozbudowanej polityki ochrony konkurencji i konsumentów Unii Europejskiej. Traktat o funkcjonowaniu Unii Europejskiej określa te polityki - odpowiednio - jako kompetencję wyłączną i kompetencję dzieloną UE. Reguły konkurencji „niezbędne do funkcjonowania rynku wewnętrznego" 49 , częściowo scharakteryzowane w tytule VIII TFUE, rozwijane są przez Radę, na wniosek Komisji i po konsultacji z Parlamentem Europejskim, a nad ich przestrzeganiem czuwa Komisja Europejska ${ }^{50}$. Ochrona konsumentów natomiast ma na celu przede wszystkim ochronę zdrowia, bezpieczeństwa i interesów gospodarczych, prawa do informacji, edukacji i organizowania się w celu zachowania interesów konsumentów. W ramach realizacji tego zadania Unia, stanowiąc w drodze zwykłej procedury prawodawczej, ma możliwość harmonizacji przepisów „urzeczywistniając rynek wewnętrzny” lub też przyjmuje środki uzupełniające, wspierające i nadzorujące polityki państw członkowskich $\mathrm{w}$ tym zakresie. Co ważne, państwa dysponują prawem tworzenia bardziej rygorystycznych przepisów ${ }^{51}$. Warto $w$ tym miejscu wprowadzić również informacje na temat Europejskiego Centrum Konsumenckiego - będącego częścią sieci Europejskich Centrów Konsumenckich (ECC-Net) — które pomaga obywatelom UE $\mathrm{w}$ dochodzeniu swoich praw konsumenckich wobec podmiotów z pozostałych państw członkowskich (w przypadku sporów transgranicznych) ${ }^{52}$.

Drugim elementem, który pojawia się w dziale I, jest założenie, iż uczeń „analizuje funkcje rynku i rozróżnia rodzaje rynków”. To właściwe miejsce do wprowadzenia pojęcia i charakterystyki Wspólnego Rynku, będącego w skali światowej rozwiązaniem ekstraordynaryjnym, o wiele bardziej zaawansowanym niż znane na świecie strefy wolnego handlu. Rozważyć można w tym obszarze, w kontekście rynku międzynarodowego, wprowadzenie również pojęcia liberalizacji handlu i stanowiących jej efekt faz integracji gospodarczej w postaci strefy wolnego handlu, unii celnej, wspólnego rynku, unii gospodarczej oraz pełnej integracji gospodarczej zakładającej pełną unifikację polityk, w tym monetarnej ${ }^{53}$. W dalszej

$48 \mathrm{~W}$ kolejnych akapitach analizowane będą punkty 1-4 z aktu Podstawy przedsiębiorczości. Treści nauczania - wymagania szczegółowe...

49 Art. 3 ust. 1 pkt b TFUE.

50 Art. 103 i 105 TFUE.

51 Art. 114 i 169 TFUE.

52 O nas, strona Europejskiego Centrum Konsumenckiego Polska, https://konsument.gov.pl/onas/ (dostęp: 5.04.2021).

53 P.J. Borkowski, Polityczne teorii integracji międzynarodowej, Warszawa 2007, s. 17-18. 
kolejności można się zastanowić nad omówieniem historii rozwoju UGW, w tym przede wszystkim trzech jej etapów. Realizując ten punkt, można również wprowadzić pojęcie czterech swobód Wspólnego Rynku, charakteryzując je szczegółowo od razu, lub też omówić je przy kolejnych, odpowiednich, punktach podstawy.

Dział II podstawy programowej to „Rynek finansowy”. W tym dziale uczniowie między innymi mają poznać 1) funkcje i formy pieniądza, 2) rodzaje papierów wartościowych oraz 3) system podatkowy. Nie bez powodu spośród siedemnastu zagadnień tego działu wybrane zostały trzy powyższe. ECU (European Currency Unit) - jednostka rozliczeniowa w Europejskim Systemie Walutowym, niekiedy określana jako prekursorka euro, a przede wszystkim sama wspólna waluta z całą pewnością wpisują się w hasło „pieniądz i jego obieg”. W kontekście wspólnej waluty mogą pojawić się informacje o banknotach i monetach, kryteriach konwergencji, emisji i obiegu tego pieniądza. Być może jest to też miejsce, w którym warto przedyskutować korzyści i zagrożenia płynące z wprowadzenia euro. Rodzaje papierów wartościowych pozwalają natomiast na ujęcie dość medialnego ostatnio tematu obligacji Unii Europejskiej, które wyemitowane w ramach instrumentu SURE mają pomóc UE, a konkretnie siedemnastu państwom członkowskim, w ochronie miejsc pracy i utrzymaniu zatrudnienia w warunkach panującej pandemii ${ }^{54}$.

Niezwykle szerokim zagadnieniem jest z kolei system podatkowy i wpływ członkostwa w UE na niego. Po pierwsze zabrania się pośrednio lub bezpośrednio nakładać przez państwa członkowskie dodatkowe lub wyższe podatki na towary pochodzące $\mathrm{z}$ innych państw członkowskich, co przyczyniać ma się do realizacji swobody przepływu towarów. Zabronione lub ograniczone są też inne działania tego typu odnoszące się do innych podatków i opłat ${ }^{55}$. Po drugie Rada, stanowiąc jednomyślnie i po konsultacji z Parlamentem Europejskim i Komitetem Ekonomiczno-Społecznym, uchwala przepisy harmonizujące przepisy dotyczące podatków obrotowych, akcyzy i innych podatków pośrednich „w zakresie, w jakim harmonizacja ta jest niezbędna do zapewnienia ustanowienia i funkcjonowania rynku wewnętrznego oraz uniknięcia zakłóceń konkurencji” ${ }^{56}$. W ramach tejże harmonizacji pojawiły się na przykład przepisy dotyczące podatku VAT (stawka podstawowa nie może być niższa niż $15 \%$, a na określonych zasadach ustanawia się stawki specjalne) oraz akcyzy (objęcie akcyzą określonych grup towarów, na przykład alkoholu czy wyrobów tytoniowych). Ponadto stworzono przepisy zarówno zapobiegające uchylaniu się od opodatkowania, jak i przeciwdziałające podwójnemu opodatkowaniu w przypadku podatków bezpośrednich od osób prawnych i od

${ }^{54}$ Komisja Europejska dokonała pierwszej emisji obligacji społecznych $w$ ramach instrumentu SURE, Serwis prasowy, Bruksela, 21.10.2020, strona Komisji Europejskiej, https://ec.europa.eu/commission/presscorner/detail/pl/IP_20_1954 (dostęp: 5.04.2021).

55 Art. 110-112 TFUE.

56 Art. 113 TFUE. 
osób fizycznych. Chodzi tu przede wszystkim o przepisy dotyczące transgranicznej działalności gospodarczej i aktywności zawodowej ${ }^{57}$.

Pojęcie rynku finansowego i zawarte w tym dziale treści (kredyty, ubezpieczenia, różne instrumenty finansowe, kwestie oszczędzania i inwestowania) prowadzą wreszcie do jednej z czterech swobód Wspólnego Rynku, czyli do swobody przepływu kapitału. Najmłodsza, bo uregulowana dopiero w Traktacie z Maastricht, swoboda zakazuje ograniczeń w przepływie kapitału między państwami członkowskimi oraz między państwami członkowskimi a państwami trzecimi ${ }^{58}$.

„Rynek pracy” to trzeci dział podstawy programowej. Wciąż w temacie swobód Wspólnego Rynku pojawia się tu sposobność wprowadzenia tej dotyczącej przepływu pracowników. Warto w tym miejscu uświadomić uczniom, że czym innym jest swoboda przemieszczania się i pobytu na terenie państw członkowskich zagwarantowana jako prawo wszystkim obywatelom Unii Europejskiej ${ }^{59}$, czym innym strefa Schengen będąca jedynie udogodnieniem pozwalającym realizować tę pierwszą, a jeszcze innym traktatowa swoboda przepływu pracowników wiążąca się z zakazem dyskryminacji ze względu na obywatelstwo przy zatrudnianiu ${ }^{60}$ i wynagradzaniu oraz przepisy dotyczące zabezpieczenia społecznego, łączenia rodzin, wzajemnego uznawania dyplomów, kwalifikacji i tak dalej ${ }^{61}$.

$\mathrm{W}$ tym dziale wiele jest punktów powiązanych z UE. Zapisane w podstawie „czynniki wpływające na równowagę na rynku pracy” otwierają pole do dyskusji o migracji zarobkowej Europejczyków czy pojęciu drenażu mózgów, niejako w kontekście skutków integracji. Punkt „rola procesu uczenia przez całe życie” kieruje w stronę dawnego programu „Uczenie się przez całe życie” (Lifelong Learning Programme), obecnie włączonego w program Erasmus+ jako edukacja dorosłych ${ }^{62}$. Sam program Erasmus+ jest $\mathrm{z}$ kolei uzupełnieniem do tematów związanych ze zbieraniem doświadczeń, kształtowaniem ścieżki edukacyjnej i kariery zawodowej, przede wszystkim w kontekście wymiany studenckiej.

W kontekście poszukiwania pracy warto wspomnieć natomiast uczniom o systemie Europass - portfolio sześciu dokumentów związanych z karierą zawodową, w tym przede wszystkim CV i listu motywacyjnego, tworzonych w wygodnym

57 Ogólnapolitykapodatkowa, NotytematyczneoUniiEuropejskiej,stronaParlamentuEuropejskiego, https://www.europarl.europa.eu/factsheets/pl/sheet/92/ogolna-polityka-podatkowa (dostęp: 5.04. 2021); Podatki pośrednie, Noty tematyczne o Unii Europejskiej, strona Parlamentu Europejskiego, https://www.europarl.europa.eu/factsheets/pl/sheet/81/podatki-posrednie (dostęp: 5.04.2021); Opodatkowanie bezpośrednie: podatek od osób fizycznych i prawnych, Noty tematyczne o Unii Europejskiej, strona Parlamentu Europejskiego, https://www.europarl.europa.eu/factsheets/pl/sheet/80/opodatkowanie-bezposrednie-podatek-od-osob-fizycznych-i-prawnych (dostęp: 5.04.2021).

58 Art. 63 TFUE.

59 Art. 20 ust. 2 pkt a, 2 pkt a TFUE.

$60 \mathrm{Z}$ wyjątkiem służby cywilnej.

61 Art. 45-48 TFUE.

62 Erasmus+. Edukacja dorostych, https://erasmusplus.org.pl/sektory/edukacja-doroslych/ (dostęp: 5.04.2021). 
internetowym kreatorze, wspomaganym dodatkowo przez sieć Krajowych Centrum Europass ${ }^{63}$. Poszukiwanie pracy można realizować za pomocą sieci EURES (European Employment Services - Europejskie Służby Zatrudnienia) - Europejskiego Portalu Mobilności Zawodowej oraz portali krajowych, będących przede wszystkim bazą milionów miejsc pracy, ale też bazą informacji o mobilności zawodowej czy też organizatorem szkoleń i Europejskich dni pracy ${ }^{64}$. Kolejny wątek w podstawie to zdobywanie doświadczeń „w formie wolontariatu, praktyk lub stażu". Stanowi on przyczynek do omówienia Wolontariatu Europejskiego i staży, które można realizować w całej Unii Europejskiej — zarówno w jej instytucjach, jak i przedsiębiorstwach i organizacjach w całej Europie. Podstawowym źródłem wiedzy jest tu Europejski Portal Młodzieżowy oraz sieć Eurodesk i dostępne tam wyszukiwarki ofert z podziałem na kategorie, państwa, grupy wiekowe i inne ${ }^{65}$.

Dział IV to „Przedsiębiorstwo”, a więc treści związane z zakładaniem i prowadzeniem różnych form działalności gospodarczej. Skoro uczeń, według podstawy, "charakteryzuje podstawowe formy organizacyjno-prawne przedsiębiorstw”, to tym samym jest zasadnym wprowadzenie pojęcia spółki europejskiej, stanowiącej rodzaj spółki akcyjnej, która umożliwia prowadzenie działalności gospodarczej w różnych państwach członkowskich na podstawie jednolitych przepisów ${ }^{66}$. W kontekście prowadzenia działalności gospodarczej pojawia się również wątek jej opodatkowania, jednakże ten został już omówiony powyżej.

Ewentualnie można by wspomnieć w tym dziale także o polityce Unii Europejskiej wobec małych i średnich przedsiębiorstw ${ }^{67}$, jednakże to jedna $z$ treści o niższym priorytecie. Dużo istotniejsze w kontekście prowadzenia działalności jest powiązanie tych tematów z trzecią i czwartą swobodą Wspólnego Rynku, a mianowicie swobodą przepływu towarów oraz swobodą przepływu usług. Zwłaszcza, że ta ostatnia obejmuje de facto swobodę przedsiębiorczości i swobodę świadczenia usług. Zgodnie z przepisami Traktatu o funkcjonowaniu Unii Europejskiej obywatele mają prawo prowadzić działalność gospodarczą w innym państwie członkowskim oraz tymczasowo oferować i świadczyć usługi w innych państwach,

63 Portal Europass, https://europass.org.pl.

64 EURES. Europejski Portal Mobilności Zawodowej, strona Komisji Europejskiej, https://ec.europa.eu/eures/public/pl/homepage; EURES. Sieć europejskich ofert pracy, strona Ministerstwa Rozwoju, Pracy i Technologii, https://eures.praca.gov.pl/ (dostęp: 5.04.2021).

65 Staże, Europejski Portal Młodzieżowy, https://europa.eu/youth/go-abroad/traineeships_pl (dostęp: 5.04.2021); Wolontariat, Europejski Portal Młodzieżowy, https://europa.eu/youth/go-abroad/volunteering_pl (dostęp: 5.04.2021); Eurowolontariat, strona Eurodesk Polska, https://www. eurodesk.pl/mobilnosc/eurowolontariat (dostęp: 5.04.2021).

66 Założeniespółkieuropejskiej(SE), portalYourEurope,https://europa.eu/youreurope/business/ running-business/developing-business/setting-up-european-company/index_pl.htm (dostęp: 5.04. 2021).

67 Więcej zob. Małe i średnie przedsiębiorstwa, Noty tematyczne o Unii Europejskiej, strona Parlamentu Europejskiego, https://www.europarl.europa.eu/factsheets/pl/sheet/63/male-i-srednie-przedsiebiorstwa (dostęp: 5.04.2021). 
pozostając jednocześnie $\mathrm{w}$ kraju pochodzenia. Swoboda przepływu towarów, w uproszczeniu, sprowadza się natomiast do zakazu wprowadzania jakichkolwiek środków ograniczających wymianę towarową pomiędzy państwami68.

Unia Europejska w całej analizowanej podstawie programowej pojawia się tylko raz, jak już zostało wskazane, i to tylko w kontekście jednego ze swoich narzędzi, a konkretnie funduszy europejskich będących jednym ze źródeł finansowania powstającej działalności gospodarczej. To rodzaj środków, które dają wiele możliwości uzyskania dofinansowania zarówno na założenie, jak i na rozwój własnej firmy. Ważne jest przekazanie uczniom informacji o istnieniu Punktu Informacyjnego Funduszy Europejskich, który zapewnia fachową pomoc w doborze i pozyskaniu funduszy ${ }^{69}$.

Tym samym kończy się analiza treści podstawy programowej, lecz nie kończą się wątki, które mogą lub wręcz powinny zostać poruszone na lekcjach. Przede wszystkim w dotychczasowym wywodzie zabrakło odniesienia do jednej z najważniejszych instytucji z punktu widzenia Unii Gospodarczej i Walutowej, czyli Europejskiego Banku Centralnego. Pewnym rozwiązaniem byłoby powiązanie tego wątku z euro lub też z działaniem Narodowego Banku Polskiego, omawianego zgodnie z podstawą w dziale II „Rynek finansowy”. Ze względu na swoją rolę może być też wyeksponowany. Niezależnie jednak od wybranego czasu, należy omówić na lekcji, czym jest EBC i Europejski System Banków Centralnych, jakie organy i zadania ma EBC, na jakich zasadach się opiera. Kluczowe będzie przede wszystkim omówienie kompetencji Banku w zakresie polityki pieniężnej i nadzoru ostrożnościowego. Kolejne zagadnienie, jakie warto zawrzeć w treściach, to krótkie powtórzenie lub wprowadzenie rodzajów i celów unijnych aktów prawnych (traktaty jako prawo pierwotne, rozporządzenia, dyrektywy i decyzje jako prawo wtórne), rodzajów kompetencji Unii Europejskiej z uwzględnieniem pojęcia harmonizacji i koordynacji oraz podstawowych zasad procedur decyzyjnych (zwłaszcza zwykłej procedury prawodawczej). Trzecim zagadnieniem może być jeszcze polityka budżetowa Unii Europejskiej, tj. procedura budżetowa, rodzaje przychodów i wydatków Unii Europejskiej, w powiązaniu z przytoczonymi już wcześniej funduszami europejskimi.

Nakoniecnależypodkreślić, iż wszystkiewskazanezagadnienia mogąbyćzarówno realizowane na lekcjach, które dotyczą poszczególnych zagadnień (na przykład swoboda przepływu kapitału na zajęciach poświęconych rynkom finansowym, zaś swoboda przepływu osób na tych omawiających rynek pracy), jak i zorganizowane jako jeden blok lekcji dotyczący Unii Gospodarczej i Walutowej Unii Europejskiej. Oba te rozwiązania mają swoje zalety i wady. Wplecenie tematów europejskich w wątki ułożone według podstawy programowej pozwoli bardziej zaakcentować

68 Art. 28, 49 i 56 TFUE.

69 Fundusze Europejskie na założenie firmy, Portal Funduszy Europejskich, 28.10.2015, https:// www.funduszeeuropejskie.gov.pl/strony/wiadomosci/fundusze-europejskie-na-zalozenie-firmy/ (dostęp: 5.04.2021). 
wszechobecność Unii Europejskiej w życiu Europejczyków, nawet tych, których walutą nie jest euro. Wymaga to jednak od nauczyciela o wiele większej wiedzy i umiejętności związanych ze stopniowym wprowadzaniem wiedzy. Rozwiązanie drugie pozwala dużo lepiej usystematyzować wiedzę na tematy europejskie - wyjście od historii integracji, przez etapy tworzenia Unii Gospodarczej i Walutowej, aż po współczesne funkcjonowanie integracji gospodarczej, omówienie zasad i instrumentów współpracy oraz poszczególnych polityk może mieć lepsze efekty w odniesieniu do rozumienia przez uczniów tych tematów. Tak jak jednak zostało podkreślone na wstępie - celem niniejszego rozdziału nie było stworzenie gotowych scenariuszy, lecz ukazanie dostępnych (i to nie wszystkich) opcji. Przegląd treści prowadzi nieuchronnie do ostatniego z „pytań badawczych” niniejszego artykułu — „Jak realizować treści europejskie?”.

\section{Środki i narzędzia nauczania elementów edukacji europejskiej w przedmiocie podstawy przedsiębiorczości a polityka informacyjna Unii Europejskiej}

Wbrew pozorom, tworzonym najczęściej na bazie stereotypów o mitycznej zbiurokratyzowanej i niedającej się zrozumieć Unii Europejskiej, nauczanie w ramach edukacji europejskiej może się opierać na ogólnodostępnych i przystępnych materiałach, czyniących je dość prostym. Polityka Unii Europejskiej zakłada bardzo szeroką działalność informacyjną i edukacyjną, która powoduje, że już same zasoby internetu dają potężną bazę do prowadzenia zajęć na temat Unii Europejskiej. Wzrost zainteresowania sprawami europejskimi powoduje, że również wiele krajowych podmiotów rozwija wiedzę na temat UE.

Pierwszym podstawowym źródłem informacji dla nauczycieli jest portal europa.eu. Znajdują się tu materiały podzielone na kilka kategorii, między innymi „Informacje o UE”; „Obszary działalności UE” (na przykład euro), „Życie, praca i podróże na obszarze UE” czy „Prowadzenie firmy”70. W ramach tego portalu prowadzony jest również „Kącik edukacyjny”. W tym miejscu nauczyciele znajdą liczne i zróżnicowane materiały dydaktyczne do prowadzenia lekcji podzielone według kategorii wiekowych oraz obszarów tematycznych, w tym interaktywne i bardzo ciekawe graficznie kalendarium Unii Europejskiej oraz gry o integracji. Aczkolwiek w przypadku tych ostatnich trzeba zaznaczyć, że większość z nich przeznaczona jest raczej dla młodszych dzieci. Ponadto jest to też kanał poszukiwania innych nauczycieli i szkół zainteresowanych współpracą, wymianą informacji i doświadczeń, zwłaszcza w ramach programów eTwinning oraz School Education Gateway ${ }^{71}$.

70 Oficjalny portal Unii Europejskiej, https://europa.eu (dostęp: 5.04.2021).

71 Kącik edukacyjny, oficjalny portal Unii Europejskiej, https://europa.eu/learning-corner/ home_pl (dostęp: 5.04.2021). 
Nauczyciele mogą poszukiwać informacji zarówno w oficjalnych dokumentach unijnych (przede wszystkim korzystając z EUR-Lex ${ }^{72}$ będącego odpowiednikiem polskiego Internetowego Systemu Aktów Prawnych), jak i w licznych broszurach informacyjnych. Jako egzemplifikację można podać taki dokument jak „Komunikat Komisji do Parlamentu Europejskiego i Rady. Nowy program na rzecz konsumentów. Poprawa odporności konsumentów na potrzeby trwałej odbudowy" i jego odpowiednik w postaci broszury „Nowy program na rzecz konsumentów. Działania na rzecz ochrony europejskich konsumentów, lata 2020-2025"73. To drugie źródło jest o wiele przystępniejsze i akcentuje najważniejsze zagadnienia. Na stronach unijnych można znaleźć liczne podobne opracowania, a ponadto $\mathrm{w}$ systemie EUR-Lex znajduje się podzielona tematycznie sekcja „Streszczenia aktów prawnych UE", w której zawarto podsumowania kluczowych aktów prawnych $\mathrm{UE}^{74}$.

Kolejnym ważnym źródłem informacji są strony internetowe poszczególnych instytucji zaangażowanych w szeroko pojętą politykę gospodarczą Unii Europejskiej. Komisja Europejska prowadzi strony informacyjne wszystkich sektorów i polityk UE, choć zaznaczyć należy, że niekiedy nie wszystkie z nich są dostępne w języku polskim. Parlament Europejski prowadzi z kolei serię „Noty tematyczne o Unii Europejskiej”. Podzielone są one na takie obszary jak system funkcjonowania UE; gospodarka, nauka i jakość życia; spójność, wzrost gospodarczy i zatrudnienie itd. W sposób szczegółowy przedstawiono tu różne aspekty działania UE, a dodatkowo, dla bardziej dociekliwych, wzbogacono to o odwołania do dokumentów, aktów prawnych, stron instytucji. Ponadto w każdej nocie znajdziemy informację na temat działalności Parlamentu w tym obszarze ${ }^{75}$.

Jednym z kluczowych źródeł jest strona internetowa i media społecznościowe prowadzone przez Europejski Bank Centralny. Odpowiedzialność i przejrzystość określone jako jedne z podstawowych, obok niezależności, zasad działania tej instytucji, powodują bardzo duży nacisk na politykę informacyjną. Na stronie EBC znajduje się dokładna charakterystyka organów, zadań i mechanizmów ich realizacji, zasad działania. Ponadto jest tam zawarty pełen przegląd bieżących działań $\mathrm{Banku}^{76}$. Z punktu widzenia prowadzenia lekcji warto natomiast podkreślić wagę zasobów zawartych na kanale EBC w serwisie YouTube. Nauczyciel znajdzie tu

72 EUR-Lex. Baza aktów prawnych Unii Europejskiej, https://eur-lex.europa.eu (dostęp: 5.04. 2021).

73 Komunikat Komisji do Parlamentu Europejskiego i Rady. Nowy program na rzecz konsumentów. Poprawa odporności konsumentów na potrzeby trwałej odbudowy, Bruksela, dnia 13 listopada 2020 roku, COM(2020) 696 final; Nowy program na rzecz konsumentów. Działania na rzecz ochrony europejskich konsumentów lata 2020-2025. Zestawienie informacji, listopad 2020, https://ec.europa. eu/info/files/new-consumer-agenda-factsheet_pl (dostęp: 5.04.2021).

74 Streszczenia aktów prawnych UE, EUR-Lex. Baza aktów prawnych Unii Europejskiej, https:// eur-lex.europa.eu/browse/summaries.html?locale=pl (dostęp: 5.04.2021).

75 Noty tematyczne o Unii Europejskiej, strona Parlamentu Europejskiego, https://www.europarl. europa.eu/factsheets/pl/home (dostęp: 5.04.2021).

76 About ECB, strona Europejskiego Banku Centralnego, https://www.ecb.europa.eu/ecb/html/ index.pl.html (dostęp: 5.04.2021). 
przede wszystkim serię filmów edukacyjnych wyjaśniających działanie Europejskiego Systemu Banków Centralnych, pokazujących zalety wprowadzenia euro, prezentujących banknoty i monety czy przedstawiających sposób powoływania Zarządu ${ }^{77}$. Mają one wersje polskojęzyczne lub polskie napisy. Szczególnie ważnym filmem jest „Historia Europejskiego Banku Centralnego” odwołująca się do historii UGW i trwająca siedem minut, co jest optymalnym czasem dla jednej jednostki lekcyjnej ${ }^{78}$.

Spośród innych instytucji zaangażowanych $\mathrm{w}$ polityki gospodarcze warto wspomnieć na przykład o Europejskim Centrum Konsumenckim w Polsce, które na swojej stronie internetowej przedstawia szczegółowo i bardzo przejrzyście, w jaki sposób i na jakich zasadach udziela pomocy konsumentom. Materiały (grafiki, ulotki ${ }^{79}$, filmiki, a nawet gry) doskonale nadają się do wbudowania w lekcje na temat ochrony konsumentów ${ }^{80}$. Ponadto strona ta może się przydać nie tylko w kontekście europejskim, ale także do lekcji poświęconych ochronie konsumentów ogólnie. Przykładowo całkiem ciekawym materiałem jest prezentacja „Co warto wiedzieć przed Black Friday”, prezentująca prawa konsumenta w sieci ${ }^{81}$.

W poprzedniej części artykułu wspomniano już o szeregu portali i sieci biur krajowych związanych z szeroko pojętą mobilnością - zarówno młodzieży, jak i dorosłych pracowników. Przypomnieć tu należy systemy Europass, EURES, Eurodesk, Europejski Portal Młodzieżowy. W zakresie funduszy unijnych pojawia się rola sieci Punktów Informacyjnych Funduszy Europejskich. Są to portale, które również realizują funkcję informacyjną i edukacyjną, tłumacząc zawiłe kwestie prawne oraz dostarczając licznych materiałów.

Spośród licznych portali i oficjalnych stron Unii Europejskiej warto wskazać jeszcze na kilka z nich. „Your Europe” to strona z pomocą i poradami dla obywateli UE i ich rodzin, a także dotyczącymi prowadzenia przedsiębiorstw w $\mathrm{UE}^{82}$. „Co Europa robi dla mnie" to z kolei serwis pokazujący wpływ Europy na codzienne

77 EBC i Eurosystem w trzyminutowym skrócie, European Central Bank, 14.11.2013, serwis YouTube, https://www.youtube.com/watch?v=X4N7iUVqDHM\&ts (dostęp: 5.04.2021); How have Europeans benefited from the euro?, European Central Bank, 28.02.2017, serwis YouTube, https://www. youtube.com/watch?v=HeXDwUsz57o\&t (dostęp: 5.04.2021); The New Face of the Euro - Europa, European Central Bank, 10.01.2013, serwis YouTube, https://www.youtube.com/watch?v=awgADXlrpX8\&t (dostęp: 5.04.2021); How are Executive Board members chosen?, European Central Bank, 7.06.2018, serwis YouTube, https://www.youtube.com/watch?v=PpNBgGu4Ahw\&t (dostęp: 5.04.2021).

78 Historia Europejskiego Banku Centralnego, European Central Bank, 19.06.2015, serwis YouTube, https://www.youtube.com/watch?v=MLggJK9aIFk\&t (dostęp: 5.04.2021).

${ }^{79}$ Por. np. Jak pomaga ECC-Net? - grafika, strona Europejskiego Centrum Konsumenckiego Polska, 27.04.2020, https://konsument.gov.pl/?mdocs-file=11514 (dostęp: 5.04.2021).

80 Publikacje, strona Europejskiego Centrum Konsumenckiego Polska, strona https://konsument.gov.pl/baza-wiedzy (dostęp: 5.04.2021); O nas, strona Europejskiego Centrum Konsumenckiego Polska...

81 Co warto wiedzieć przed Black Friday, strona Europejskiego Centrum Konsumenckiego Polska, 1.12.2019, https://konsument.gov.pl/?mdocs-file=11069 (dostęp: 5.04.2021).

82 Portal Your Europe, https://europa.eu/youreurope/\#pl (dostęp: 5.04.2021). 
życie jej mieszkańców z podziałem na informacje o tejże działalności „W moim regionie”, „w moim życiu” i ogólnie jako „obszary działań” ${ }^{33}$. Niezwykle ciekawym projektem jest TAXEDU - pilotażowy projekt Unii, mający na celu edukowanie młodych obywateli UE o podatkach i ich wpływie na życie. Materiały dostępne w serwisie podzielone są na trzy kategorie wiekowe: 9-12 lat, 13-17 lat i 18-25 lat. Treści przekazywane są w formie gier, e-learningów i microlearningów (materiałów wideo), zaś nauczyciele znajdą tu ofertę zasobów i wskazówek na lekcje ${ }^{84}$.

Kolejnym z niezwykle ważnych źródeł są zasoby Urzędu Publikacji Unii Europejskiej. Nauczyciel może stąd pobrać lub, co jeszcze ważniejsze, zamówić (w większości przypadków) bezpłatne wydruki różnych materiałów. Poszczególne publikacje są aktualizowane w obliczu zmieniających się przepisów prawa czy rozwoju polityk. Znajdują się tu różne mapy Unii Europejskiej (na przykład mapa pod tytułem Strefa euro) ${ }^{85}$. Seria „UE w skrócie” obejmuje działania Unii w różnych obszarach i stanowi około jednostronicowe opracowania wybranych tematów (na przykład Jednolity Rynek, cła, system podatkowy ${ }^{86}$. Wydzielono również sekcję dla nauczycieli i studentów ${ }^{87}$. Bardzo ciekawą publikacją dostępną na stronie Urzędu jest pozycja „Unia Europejska. Czym jest i czym się zajmuje”, w której podano najważniejsze informacje o UE, opisano jej polityki (w tym kluczowe dla tej pracy polityki gospodarcze) oraz sposoby podejmowania decyzji ${ }^{88}$. Podobny przewodnik, choć nieco już przestarzały (choćby w obliczu Brexitu) i niestety nieaktualizowany, a dotyczący systemu instytucjonalnego, to „Jak działa Unia Europejska. Przewodnik po instytucjach europejskich" ${ }^{\text {"9 }}$. Urząd przygotował również szereg publikacji przeznaczonych stricte dla nauczycieli i uczniów. „Europa w 12 lekcjach” 90 oraz „UE \& ja” 91 to w zasadzie gotowe scenariusze lekcji i materiały do dowolnego wykorzystania na zajęciach. Znajdują się w nich takie tematy jak euro,

83 Portal Co Europa robi dla mnie, https://www.what-europe-does-for-me.eu/pl/home (dostęp: 5.04.2021).

84 Portal TAXEDU, https://europa.eu/taxedu/home_pl (dostęp: 5.04.2021).

85 Mapy, strona Urzędu Publikacji Unii Europejskiej, https://op.europa.eu/pl/web/general-publications/maps (dostęp: 5.04.2021).

86 UE $w$ skrócie, strona Urzędu Publikacji Unii Europejskiej, https://op.europa.eu/pl/web/general-publications/eu-at-a-glance (dostęp: 5.04.2021).

87 Studenci i nauczyciele, strona Urzędu Publikacji Unii Europejskiej, https://op.europa.eu/pl/ web/general-publications/teachers (dostęp: 5.04.2021).

88 Unia Europejska. Czym jest i czym się zajmuje, Urząd Publikacji Unii Europejskiej, 1.02.2020, https://op.europa.eu/pl/publication-detail/-/publication/ac0a88a6-4369-11ea-b81b-01aa75ed71a1/ language-pl/format-PDF/source-183945552 (dostęp: 5.04.2021).

89 Jak działa Unia Europejska. Przewodnik po instytucjach europejskich, Urząd Publikacji Unii Europejskiej, 29.10.2014, https://op.europa.eu/pl/publication-detail/-/publication/9a6a89dc-4ed7-4bb9-a9f7-53d7f1fb1dae (dostęp: 5.04.2021).

90 Europa w 12 lekcjach, Urząd Publikacji Unii Europejskiej, 3.07.2018, https://op.europa.eu/ $\mathrm{pl} /$ publication-detail/-/publication/a5ba73c6-3c6a-11e8-b5fe-01aa75ed71a1/language-pl/format-PDF/source-183946246 (dostęp: 5.04.2021).

91 UE \& ja, Urząd Publikacji Unii Europejskiej, 1.02.2020, https://op.europa.eu/pl/publication-detail/-/publication/955ebbaf-4366-11ea-b81b-01aa75ed71a1/language-pl/format-PDF/sour- 
Wspólny Rynek, Erasmus+ i inne. Bardzo atrakcyjnymi wizualnie broszurami są z kolei „Krótki przewodnik po euro"92 oraz „Jedna waluta dla jednej Europy”93 przeznaczone właśnie do pracy w warunkach szkolnych. Ostatnią serią, na którą warto zwrócić szczególną uwagę, jest seria „Zrozumieć politykę Unii Europejskiej”, w której znajdziemy takie opracowania jak „Rynek wewnętrzny. Od kryzysu do nowych możliwości: jak zapewnić dobrobyt społeczeństwu i przedsiębiorstwom”, „Bankowość i finanse. Dobrze funkcjonujący jednolity rynek usług finansowych przyczynia się do dobrobytu materialnego, stabilności i wzrostu gospodarczego", „Konkurencyjność. Lepsze funkcjonowanie rynków”. Są to więc już pozycje dużo bardziej szczegółowe, które nauczycielom mogą przydać się przede wszystkim do pogłębienia i uporządkowania własnej wiedzy. Jak już zostało powiedziane, na stronie internetowej Urzędu znajdują się pliki PDF w różnych językach, które można pobrać, istnieje również możliwość zamówienia tych materiałów, choć niektóre z nich są płatne. Co ważne, instytucje takie jak Przedstawicielstwo Parlamentu Europejskiego w Polsce, Przedstawicielstwo Komisji Europejskiej w Polsce czy Punkty Informacji Europejskiej Europe Direct mają te publikacje dostępne na miejscu lub umożliwiają ich zamówienie przez nauczycieli i placówki oświatowe.

W tej części artykułu znalazł się jedynie wąski i subiektywny (dokonany bowiem z punktu widzenia nie naukowca, lecz raczej praktyka, to jest czynnego nauczyciela wiedzy o społeczeństwie w liceum) wybór źródeł i materiałów, co więcej skupiający się jedynie na zasobach internetu. Na marginesie można zauważyć, że realizowane przez ponad rok nauczanie zdalne w warunkach COVID pokazało, jak cenne jest to źródło. Wiele możliwości zostało pominiętych, ponieważ także krajowe instytucje dostarczają licznych informacji i materiałów do wykorzystania. Ministerstwa czy Narodowy Bank Polski ${ }^{94}$ również prowadzą działania informacyjne i edukacyjne w tym zakresie. Pominięta została także literatura naukowa ${ }^{95}$. Nie da się jednak ukryć, że sama Unia Europejska dostarcza nieograniczonej ilości materiałów.

ce-183946684 (dostęp: 5.04.2021). Istnieje również starsze wydanie tej publikacji wraz z podręcznikiem dla nauczyciela pt. „Europa. Informator dla młodzieży”.

${ }^{92}$ Krótki przewodnik po euro, Urząd Publikacji Unii Europejskiej, 01.02.2020, https://op.europa. $\mathrm{eu} / \mathrm{pl} /$ publication-detail/-/publication/2a9e2a82-4412-11ea-b81b-01aa75ed71a1/language-pl/format-PDF/source-183946805 (dostęp: 5.04.2021).

93 Jedna waluta dla jednej Europy, Urząd Publikacji Unii Europejskiej, 1.02.2020, https://op.europa.eu/pl/publication-detail/-/publication/2eb6397b-436a-11ea-b81b-01aa75ed71a1/language-pl/ format-PDF/source-183947545 (dostęp: 5.04.2021).

94 Jako przykład można podać scenariusz lekcji o Unii Gospodarczej i Walutowej zamieszczony na portalu edukacyjnym NBP czy też serię filmów o euro opublikowanych na kanale NBP w serwisie YouTube.

95 Zob. np. Integracja europejska. Ćwiczenia, red. K.A. Wojtaszczyk, Ł. Zamęcki, Warszawa 2012, zawierająca scenariusze zajęć o UGW; A. Dąbrowski, Ład gospodarczy UE, [w:] Integracja europejska..., s. 187-190. 


\section{Zakończenie}

Przeprowadzona analiza pozwala potwierdzić postawioną hipotezę: rozszerzenie programu nauczania podstaw przedsiębiorczości o elementy edukacji europejskiej nie tylko może być pomocne dla lepszego rozumienia przez uczniów procesów gospodarczych zachodzących w skali całego kontynentu, ale również wydaje się absolutnie niezbędne dla wyjaśnienia procesów zachodzących w narodowym systemie gospodarki rynkowej. Jest to obszar, który w podstawie programowej został zwyczajnie pominięty. I tak jak nie da się nauczać historii Polski w oderwaniu od historii powszechnej, tak nie da się też skutecznie przedstawić procesów gospodarczych w Polsce bez ukazania ich europejskiego podłoża.

Tytułem zakończenia, nieco przewrotnie i posługując się pewną metaforą, należy stwierdzić, że niczym w dobrej powieści kryminalnej nauczyciel ma motyw, sposobność i narzędzie do tego, by wprowadzić do nauczania podstaw przedsiębiorczości elementy edukacji europejskiej.

Motywem będzie przede wszystkim chęć edukowania młodych Europejczyków, którzy będą świadomymi obywatelami Unii Europejskiej, korzystającymi z jej osiągnięć. Młodzi ludzie muszą zrozumieć, że polska gospodarka nie jest samotną wyspą, systemem autarkicznym, lecz częścią większej całości - zjednoczonej Europy. I choć, jak się wydaje, nie ma obecnie klimatu politycznego do rozmowy o rozwoju i zacieśnianiu integracji europejskiej, to nawet ewentualna dyskusja o pójściu ścieżką brytyjską powinna się toczyć w oparciu o racjonalną i merytoryczną dyskusję.

Sposobność to przede wszystkim wykazana w części drugiej i trzeciej potrzeba uzupełnienia treści o tematy $\mathrm{z}$ zakresu edukacji europejskiej oraz miejsce na to w postaci pięciu (maksymalnie trzynastu) godzin lekcyjnych. Liczne punkty podstawy programowej tego przedmiotu pozostają wręcz niepełnymi bez poszerzenia o europejski ich kontekst.

I wreszcie narzędzie. Unia Europejska, stawiając sobie za cel przybliżenie jej działania Europejczykom, zbudowała ogromną bazę informacji, materiałów, zasobów skierowanych do różnych grup wiekowych, społecznych i zawodowych. Polityka edukacyjna i informacyjna UE przekłada się na niezwykłą dostępność informacji i gotowych rozwiązań edukacyjnych dla nauczycieli.

\section{Bibliografia}

\section{Opracowania}

Arnold R., Barcz J., Michałowska-Gorywoda K., Tschäpe P., Parlament Europejski oraz parlamenty Polski i Niemiec w nowej architekturze europejskiej, Warszawa 2005.

Barcz J., Parlamenty narodowe w procesie integracji europejskiej. Wyzwania przed parlamentem polskim, [w:] R. Arnold, J. Barcz, K. Michałowska-Gorywoda, P. Tschäpe, Parlament Europejski oraz parlamenty Polski i Niemiec w nowej architekturze europejskiej, Warszawa 2005, s. 133. 
Borkowski P.J., Polityczne teorii integracji międzynarodowej, Warszawa 2007.

Edukacja europejska - zarys problematyki, red. T. Michalski, Pelplin 2005.

For a Community Policy on Education. Report by Henri Janne, „Bulletin of the European Communities Supplement" 1973, nr 10.

Furman B., W centrum uwagi. Program nauczania wiedzy o społeczeństwie dla liceum ogólnokształcacego i technikum zakres rozszerzony ze zintegrowanymi treściami z zakresu podstawowego, Warszawa 2019.

Integracja europejska. Ćwiczenia, red. K.A. Wojtaszczyk, Ł. Zamęcki, Warszawa 2012.

Polska w Unii Europejskiej - od stowarzyszenia do piętnastolecia członkostwa. Monografia jubileuszowa dedykowana Profesor Elżbiecie Kaweckiej-Wyrzykowskiej, red. A.A. Ambroziak, A.D. Szypulewska-Porczyńska, Warszawa 2020.

Rojewska M., Ewolucja myśli europejskich ruchów federalistycznych, „Myśl Ekonomiczna i Polityczna" 2018, nr 1 (60).

Włoch A., Edukacja europejska. Założenia, perspektywy, funkcje społeczne. Krytyczne spojrzenie, Kraków 2016.

\section{Źródła internetowe}

Brexit has raised support for the European Union, „Flashlight Europe” 2, 2016, Bertelsmann Stiftung, https://www.bertelsmann-stiftung.de/fileadmin/files/user_upload/EZ_flashlight_europe_02_2016 _EN.pdf.

Centralna Komisja Egzaminacyjna, Wstępne informacje o wynikach egzaminu maturalnego przeprowadzonego w terminie głównym (w czerwcu) 2020 r., 11.08.2020, http://cke.gov.pl/images/_EGZAMIN_MATURALNY_OD_2015/Informacje_o_wynikach/2020/20200811\%20Wstepne\%20 informacje\%20o\%20wynikach\%20egzaminu\%20maturalnego\%202020.pdf.

Erasmus+, https://erasmusplus.org.pl/.

EURES. Europejski Portal Mobilności Zawodowej, strona Komisji Europejskiej, https://ec.europa. eu/eures/public/pl/homepage.

EURES. Sieć europejskich ofert pracy, strona Ministerstwa Rozwoju, Pracy i Technologii, https:// eures.praca.gov.pl/.

EUR-Lex. Baza aktów prawnych Unii Europejskiej, https://eur-lex.europa.eu.

European Central Bank, serwis YouTube, https://www.youtube.com/user/ecbeuro.

Europejski Portal Młodzieżowy, https://europa.eu/youth/home_pl.

Kacik edukacyjny, oficjalny portal Unii Europejskiej, https://europa.eu/learning-corner/home_pl.

Komisja Europejska dokonała pierwszej emisji obligacji społecznych $w$ ramach instrumentu SURE, Serwis prasowy, Bruksela, 21.10.2020, strona Komisji Europejskiej, https://ec.europa.eu/commission/presscorner/detail/pl/IP_20_1954.

Marchewka zaklasyfikowana jako owoc? To nie absurd, ale uwzględnienie tradycji, [w:] Fake news czy prawda? Sprawdź!, strona internetowa Przedstawicielstwa Komisji Europejskiej w Polsce, 10.05. 2019, https://ec.europa.eu/poland/news/190510_fake_news_pl.

Narodowy Bank Polski, serwis YouTube, https://www.youtube.com/user/NBPtv.

Narodowy Bank Polski. Departament Edukacji i Wydawnictw NBP, Prezentacja wyników „Badania świadomości $i$ wiedzy ekonomicznej Polaków", https://www.nbp.pl/ edukacja/badania/wiedza-ekonomiczna-polakow.pdf.

NBP — Portal Edukacji Ekonomicznej, https://www.nbportal.pl/.

Noty tematyczne o Unii Europejskiej, strona Parlamentu Europejskiego, https://www.europarl.europa. eu/factsheets/pl/home.

Nowy program na rzecz konsumentów. Działania na rzecz ochrony europejskich konsumentów lata 2020-2025. Zestawienie informacji, listopad 2020, https://ec.europa.eu/info/files/new-consumer-agenda-factsheet_pl. 
Oficjalny portal Unii Europejskiej, https://europa.eu.

Portal Co Europa robi dla mnie, https://www.what-europe-does-for-me.eu/pl/home.

Portal Europass, https://europass.org.pl.

Portal Funduszy Europejskich, https://www.funduszeeuropejskie.gov.pl/.

Portal Sięgnij po więcej, wyszukiwarka szkół ponadpodstawowych prowadzonych przez m.st. Warszawę, https://wyszukiwarka.spw.edu.pl/.

Portal TAXEDU, https://europa.eu/taxedu/home_pl.

Portal Your Europe, https://europa.eu/youreurope/\#pl.

Przybysz A., Europejski wymiar szkolnictwa wyższego, „Edukacyjne dyskursy. Internetowe Pismo Pedagogiczne Instytutu Pedagogiki Uniwersytetu Szczecińskiego” 15.06.2004, http://www.edukacyjne.dyskursy.univ.szczecin.pl/europejski.htm.

Roguska B., Narastanie obaw związanych $z$ wprowadzaniem euro, CBOS, Komunikat z badań 151/ 2014, listopad 2014, www.cbos.pl/SPISKOM.POL/2014/K_151_14.PDF.

Standard Eurobarometer 87. Spring 2017. Graphs EN - European citizenship, https://ec.europa.eu/ commfrontoffice/publicopinion/index.cfm/ResultDoc/download/DocumentKy/82865.

Standard Eurobarometer 87. Spring 2017. The key indicators. Poland, https://ec.europa.eu/commfrontoffice/publicopinion/index.cfm/ResultDoc/download/DocumentKy/79546.

Standard Eurobarometer 91. Spring 2019. Europeans' views on the priorities of the European Union. Report, https://ec.europa.eu/commfrontoffice/publicopinion/ index.cfm/ResultDoc/download/ DocumentKy/88102.

Standard Eurobarometer 91. Spring 2019. Public opinion in the European Union. Report, https://ec.europa.eu/commfrontoffice/publicopinion/index.cfm/ResultDoc/download/DocumentKy/88420.

Standard Eurobarometer 92. Autumn 2019. Public opinion in the European Union. Raport, https://ec.europa.eu/commfrontoffice/publicopinion/index.cfm/ResultDoc/down load/DocumentKy/90258.

Streszczenia aktów prawnych UE, EUR-Lex. Baza aktów prawnych Unii Europejskiej, https://eur-lex. europa.eu/browse/summaries.html?locale $=$ pl.

Strona Eurodesk Polska, https://www.eurodesk.pl/.

Strona Europejskiego Banku Centralnego, https://www.ecb.europa.eu/ecb/html/ index.pl.html.

Strona Europejskiego Centrum Konsumenckiego Polska, https://konsument.gov.pl.

Strona Urzędu Publikacji Unii Europejskiej, https://op.europa.eu/pl/.

\section{Akty prawne}

Dyrektywa Rady 2001/113/WE z dnia 20 grudnia 2001 roku odnosząca się do dżemów owocowych, galaretek i marmolady oraz słodzonego przecieru z kasztanów przeznaczonych do spożycia przez ludzi, Dz.Urz. UE L 10 z 12.01.2002.

Komunikat Komisji do Parlamentu Europejskiego i Rady. Nowy program na rzecz konsumentów. Poprawa odporności konsumentów na potrzeby trwałej odbudowy, Bruksela, 13.11.2020, $\operatorname{COM}(2020) 696$ final.

Rozporządzenie Ministra Edukacji Narodowej z dnia 30 stycznia 2018 roku w sprawie podstawy programowej kształcenia ogólnego dla liceum ogólnokształcącego, technikum oraz branżowej szkoły II stopnia, Dz.U. z 2018 r. poz. 467 z późn. zm.

Rozporządzenie Ministra Edukacji Narodowej z dnia 3 kwietnia 2019 roku w sprawie ramowych planów nauczania dla publicznych szkół, Dz.U. z 2019 r. poz. 639 z późn. zm.

Traktat o funkcjonowaniu Unii Europejskiej, wersja skonsolidowana, Dz.Urz. UE C 202 z dnia 7.06.2016.

Uchwała Senatu Rzeczypospolitej Polskiej z dnia 18 czerwca 2020 roku o znaczeniu edukacji europejskiej, Dz.Urz. RP z 2020 r. poz. 596. 